\title{
準 3 次元数値モデルによる河川分流点周辺の 河床変動シミュレーション QUASI-3D NUMERICAL SIMULATIONS OF FLOW AND BED VARIATION IN DIVERSION OF A RIVER
}

\author{
坂本 洋 $^{1} \cdot$ 重枝末玲 $^{2} \cdot$ 秋山壽一郎 $^{3} \cdot$ 新谷恭平 $^{4}$ \\ Hiroshi SAKAMOTO, Mirei SHIGE-EDA, Juichiro AKIYAMA and Kyouhei SHINTANI \\ 1正会員（株）建設技術研究所九州支社河川部 (テ810-0041 福岡市中央区大名2-4-12 CTI福岡ビル) \\ 九州工業大学大学院 工学研究科建設社会工学専攻博士後期課程 \\ 2正会員 博士(工) 九州工業大学大学院准教授 工学研究院建設社会工学研究系 \\ ( ₹804-8550 北九州市戸畑区仙水町1-1) \\ 3 フェロー会員 Ph.D. 九州工業大学大学院教授 工学研究院建設社会工学研究系 (同上) \\ 学生会員 九州工業大学大学院 工学府建設社会工学専攻博士前期課程（同上）
}

\begin{abstract}
Numerical simulations for flood flows and bed variation in a diversion of a river were performed using a quasi-three dimensional numerical model. The vertically averaged and moment equations was used as governing equations to allow for the incorporation of pre-assumed linear distribution of horizontal velocity distributions. The model is based on finite volume method using HLLC(Harten, Lax and van Leer and Contact(2004)) numerical flux, which is one of a Riemann solver. The model is verified against two experimental data of flows and bed variation in a diversion of a river. It shows that the model has ability to reproduce the flow and bed variation in a diversion of a river, but the more improvement is needed to predict reasonable accuracy.
\end{abstract}

Key Words : diversion of a river, experiments, characteristics of flow and bed variation, streamline, water surface profile, quasi-3D numerical model

\section{1. はじめに}

近年，河川の維持管理は，本格的な計画管理へと移行 している1). 計画的な維持管理を行うためには，出水や 河川改修が河床や河道に及ぼすインパクト，すなわち出 水や河川改修によって生じる中長期的な(1)河床や河道の 変動2),3),(2)河床材料の質の変化 ${ }^{4)}$, (3)(1)と(2)よって形

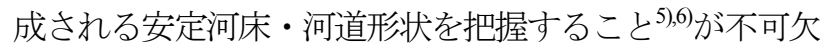
であり, これらの予測を目的とした様々な研究がなされ ている.

河川分流点は, 分流角度, 分流点上下流の川幅などの 河道の平面形状, 各河川の下流端の水位, 分流堰等の構 造物によって, 流況, 分派流量, 分派流砂量が変化する ため，中長期的な河床位とその質の縦横断変化に大きな 影響を及ぼす。そのため，河川分流点は，河川の維持管 理上，極めて重要な地点である.

河川分流点での流れや河床変動に関寸る研究では, (1) 流れや河床変動に大きな影響を及ぼす流量配分比や流砂 量配分比の予測法の開発7,8,89)，(2)分流点周辺の流れやそ れによって生じる河床変動の予測を目的とした数值モデ
ルの開発100,11,12),13,14),15)などが行われている. 特に, 近年 では, 分流点周辺のように水深平均の流れと底面との流 れの間に差が生じるような平面2次元モデルでは予測が 困難な流れを，水深平均モデルで取り扱う準3次元モデ ルの開発133,14),15)が積極的に行われている. 著者らは，準 3次元洪水流モデル ${ }^{15)}$ 開発し，分流点周辺の流れへの 適用性について検討した結果, 同モデルが河床変動を予 測する上で重要な底面での流向を十分な精度で再現でき ることを示した. このようなモデルが的確に中長期の河 床変動を予測することが可能となれば，維持管理計画を 策定するツールとして有用なものになると考えられるが, 準3次元モデルの分流点周辺の河床変動への適用性につ いて十分にわかっていないのが現状である.

本研究は, 以上のような背景を踏まえ, 分流点周辺の 維持管理計画を検討が可能な準3次元洪水流・河床変動 モデルの開発を最終的な目的としている．ここでは，著 者らの開発した準3次元河床変動モデル ${ }^{15)}$ に改良を加え るとともに，混合砂碩河床変動モデルを組み込むことで， 新たな準3次元混合砂磼河床変動モデルを構築した. さ らに，同モデルを分流点周辺の一様砂および混合砂碩河 床での移動床実験結果に適用し，同モデルの河床変動お 


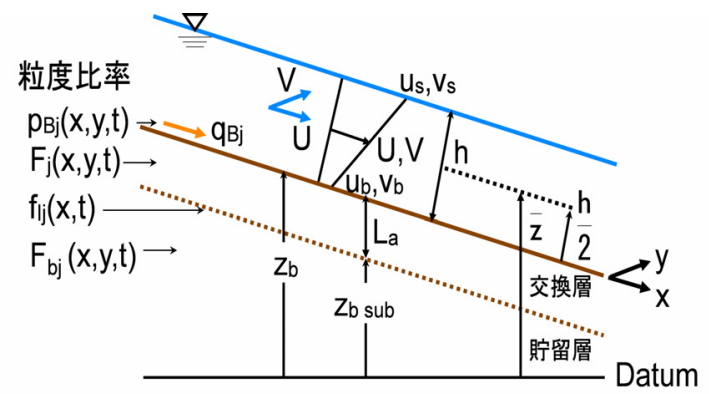

図-1 流れと河床変動の定義図

よび河床の質の変化の予測精度を検証するとともに，維 持管理計画検討ツールとしての今後の課題について検討 した.

\section{2. 準3次元混合砂碟河床変動モデルの概要}

準3次元混合砂砂河床変動モデルは，著者らが開発し た有限体積法と近似リーマン解法に基づく準3次元河床 変動モデル15)をべースとして，以下の(1)～(3)の改良と(4) 混合砂礫河床変動モデルを組み込んだ新たなモデルであ る. 流れのモデルには，(1)モーメント方程式に鉛直方向 の流速分布に応じたせん断応力と(2)底面せん断力に底面 流速の影響を組み込むとともに，(3)モーメント方程式の

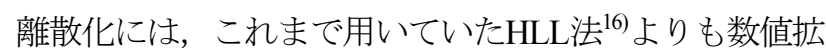
散が小さいHLLC法 ${ }^{17)}$ 適用するなどの改良を加えた. 河床変動モデルには, 新たに(4)混合砂礫河床変動モデル 18)を導入した。

\section{（1）基礎方程式}

\section{a）流れの基礎方程式}

流れの基礎方程式は，式(1)の連続の式と運動方程式お よびモーメント方程式である. これらの式は, 圧力 $p$ の 鉛直分布を静水圧分布で， $x, y$ 軸方向の流速 $u, v$ の流速 分布を式(2)のように線形で近似し，重み関数を1及び $2(z-\bar{z}) / h$ とし, 連続の式及びReynoldsの運動方程式を水 深積分することで求められる.

$$
\begin{gathered}
\frac{\partial \boldsymbol{U}}{\partial t}+\frac{\partial \boldsymbol{E}}{\partial x}+\frac{\partial \boldsymbol{F}}{\partial y}+\boldsymbol{M}_{1}+\boldsymbol{M}_{2}+\boldsymbol{S}_{1}+\boldsymbol{S}_{2}=0 \\
\boldsymbol{U}=\left(h, U h, V h, u^{\prime} h, v^{\prime} h\right)^{T} ; \\
\boldsymbol{E}=\left(U h, U^{2} h+\frac{1}{3} u^{\prime 2} h+\frac{1}{2} g h^{2}, U V h+\frac{1}{3} u^{\prime} v^{\prime} h, U u^{\prime} h, U v^{\prime} h\right)^{T} ; \\
\boldsymbol{F}=\left(V h, U V h+\frac{1}{3} u^{\prime} v^{\prime} h, V^{2} h+\frac{1}{3} v^{\prime 2} h+\frac{1}{2} g h^{2}, V u^{\prime} h, V v^{\prime} h\right)^{T} ; \\
\boldsymbol{M}_{1}=\left(0,0,0, u^{\prime} h \frac{\partial U}{\partial x}, u^{\prime} h \frac{\partial V}{\partial x}\right)^{T} ; \boldsymbol{M}_{2}=\left(0,0,0, v^{\prime} h \frac{\partial U}{\partial y}, v^{\prime} h \frac{\partial V}{\partial y}\right)^{T} ; \\
\boldsymbol{S}_{1}=\left(0, g h \partial z_{b} / \partial x, h \partial z_{b} / \partial y, 0,0\right)^{T} ; \\
\boldsymbol{S}_{2}=\left(0, \tau_{b x} / \rho, \tau_{b y} / \rho,-3 \tau_{b x} / \rho+6 \bar{\tau}_{z x} / \rho,-3 \tau_{b y} / \rho+6 \bar{\tau}_{z y} / \rho\right)^{T} \\
u=U+u^{\prime}(2 \eta-1), \quad v=V+v^{\prime}(2 \eta-1)
\end{gathered}
$$

ここに, $\boldsymbol{U}=$ 保存量ベクトル $, \boldsymbol{E}, \boldsymbol{F}=x, y$ 方向の流束ベク トル， $\boldsymbol{M}_{1,2}=$ 非保存項ベクトル， $\boldsymbol{S}_{1}=$ 河床勾配ベクトル, $\boldsymbol{S}_{2}=$ せん断応力べクトル, $U, V=x, y$ 方向の水深平均流 速, $u^{\prime}, v^{\prime}=$ 流速の偏差成分, $h=$ 水深, $g=$ 重力加速度, $\eta=\left(z-z_{b}\right) / h, z=$ 基準面からの高さ(鉛直上向きを正) $z_{b}=$ 河 床高, $\bar{z}=z_{b}+h / 2, z=$ 鉛直方向である. 図-1に定義図 を示す.これらの方程式では, 水深規模の渦による運動 量交換は，モーメント方程式から求める $u^{\prime}, v^{\prime}$ で評価さ れ, これらを介して, 水深平均の運動量保存に影響を及 ぼす。

せん断応力ベクトル $\boldsymbol{S}_{2}$ 中の $\tau_{b x, y}, \bar{\tau}_{z x, y}$ は, 底面せん 断応力と鉛直方向の流速差によるせん断応力であり，そ れぞれ式(3)と式(4)で表される．式(3)では，流れが等流 状態にない場合, 流速の偏差成分 $u^{\prime}, v^{\prime}$ によって, つま り, 底面流速によって底面せん断力の大きさと方向を変 化させることで, 底面での流れが河床変動に及ぼす影響 を考慮している，なお，流速の偏差成分 $u^{\prime} ， v^{\prime} か ゙$ 等流状 態の值 $\left(u^{\prime}=1 /(4 \alpha \phi) U, \quad v^{\prime}=1 /(4 \alpha \phi) V\right)$ となった場合には，式 (3)は等流時の底面せん断力と一致することになる.

$$
\begin{gathered}
\frac{\tau_{b x}}{\rho}=\frac{1}{\phi^{2}}\left[\left\{U\left(1+\frac{1}{4 \alpha} \frac{1}{\phi}\right)-u^{\prime}\right\}^{2}+\left\{V\left(1+\frac{1}{4 \alpha} \frac{1}{\phi}\right)-v^{\prime}\right\}\right] \frac{u_{b}}{\sqrt{u_{b}^{2}+v_{b}^{2}}} \\
\frac{\tau_{b y}}{\rho}=\frac{1}{\phi^{2}}\left[\left\{U\left(1+\frac{1}{4 \alpha} \frac{1}{\phi}\right)-u^{\prime}\right\}^{2}+\left\{V\left(1+\frac{1}{4 \alpha} \frac{1}{\phi}\right)-v^{\prime}\right\}^{2}\right] \frac{v_{b}}{\sqrt{u_{b}^{2}+v_{b}^{2}}} \\
\frac{\bar{\tau}_{z x}}{\rho}=\bar{v}_{t} \frac{\partial u}{\partial x}=\bar{v}_{t} \frac{2 u^{\prime}}{h}, \quad \frac{\bar{\tau}_{z y}}{\rho}=\bar{v}_{t} \frac{\partial v}{\partial y}=\bar{v}_{t} \frac{2 v^{\prime}}{h}
\end{gathered}
$$

ここに, $u_{\mathrm{b}}, v_{\mathrm{b}}=x, y$ 方向の底面流速 $\left(u_{\mathrm{b}}=U-u^{\prime}, v_{\mathrm{b}}=V-v^{\prime}\right)$, $\phi=$ 流速係数であり，マニング・ストリックラー型の式 $\phi$ $=\alpha_{\mathrm{T}}\left(h / k_{s}\right)^{1 / 6}$ を用いた. 式中の係数 $\alpha_{\mathrm{T}}$ は, 平坦床での岸・ 黒木の抵抗則 ${ }^{19)}$ と整合するように $\alpha_{\mathrm{T}}=6.9$ 与えた. ここで, $k_{s}=$ 粗度高さであり, 河床表層の累加分率 $90 \%$ 粒径 $D_{s 90}$ を 用いた. また, $\bar{v}_{t}=$ 水深平均の渦動粘性係数であり, 式 (2)の流速分布についても $\bar{v}_{t}=\alpha u_{*} h$ で近似できるとした. ここに, $u_{*}=$ 摩擦速度, $\alpha=$ 係数 $(=\kappa / 6), \quad \kappa=$ カルマン定数 (=0.41)である.

\section{b）河床変動の基礎方程式}

準3次元混合砂㗜河床変動モデルの基礎方程式は，全 粒径の流砂の連続の式と，同式と交換層の概念に基づく 粒径別の流砂の連続の式 ${ }^{(20)}$ から導かれる交換層での粒度 比率 $F_{j}$ の時間変化の方程式であり, それぞれ式(5)と式(6) で表される.

$$
\begin{aligned}
& \left(1-\lambda_{b}\right) \frac{\partial z_{b}}{\partial t}+\frac{\partial\left(q_{B T x}\right)}{\partial x}+\frac{\partial\left(q_{B T_{y}}\right)}{\partial y}=0 \\
& \left(1-\lambda_{b}\right)\left[L_{a} \frac{\partial F_{j}}{\partial t}+\left(F_{j}-f_{I j}\right) \frac{\partial L_{a}}{\partial t}\right]= \\
& -\left\{\frac{\partial\left(q_{B x j}\right)}{\partial x}+\frac{\partial\left(q_{B, j}\right)}{\partial y}-f_{I j}\left(\frac{\partial\left(q_{B T x}\right)}{\partial x}+\frac{\partial\left(q_{B T y}\right)}{\partial y}\right)\right\}
\end{aligned}
$$

ここに, $\lambda_{\mathrm{b}}=$ 河床材料の空隙率, $q_{B T x}, q_{B T y}=x, y$ 方向の流 


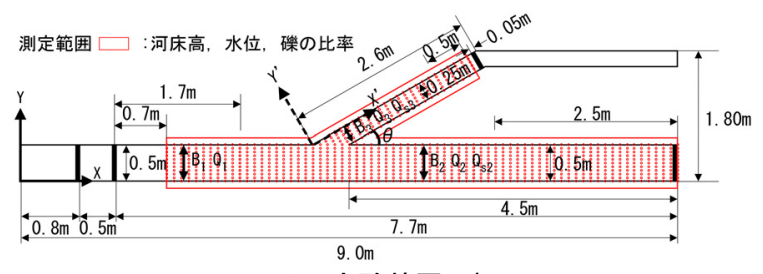

図-2 実験装置の概要

表-1 実験条件
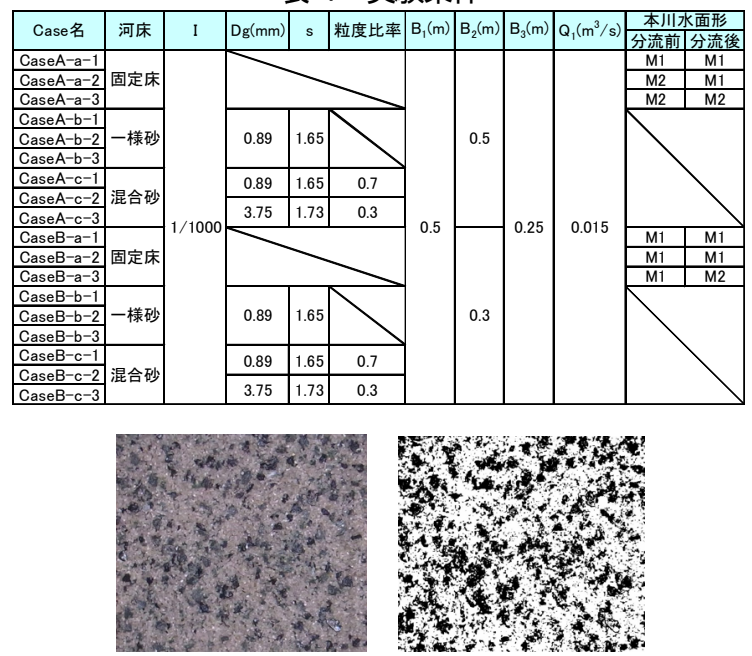

図-3 河床表層の粒度分布 (左 : 撮影写真, 右 : 2值化画像)

砂量， $j=j$ 番目の土砂の粒径を表す添字， $f_{I j}=$ 交換層と貯 留層との境界での粒度比率, $L_{a}=$ 交換層の厚さ, $F_{j}=$ 交換 層での粒度比率， $q_{B T x}, q_{B T y}=x, y$ 方向の全流砂量である. 図-1に定義図を示す。

$x, y$ 方向の流砂量は，全流砂量 $q_{B T}$ と粒径別流砂量 $q_{B j}$ を, 式(7)のように底面流速に沿って $x, y$ 方向に分配した。 な お，本モデルのように三角形非構造格子を用いた場合に， 最急勾配方向の求め方が確立されているわけではないの で，ここでは河床勾配が流砂量方向へ及ぼす影響は考慮 していない.この点については，今後検討したいと考え ている.

$$
\begin{gathered}
q_{B x j}=q_{B j} \cos \theta, \quad q_{B y j}=q_{B j} \sin \theta \\
q_{B T x}=q_{B T} \cos \theta, \quad q_{B T y}=q_{B T} \sin \theta \\
\cos \theta=u_{b} / \sqrt{u_{b}^{2}+v_{b}^{2}} ; \sin \theta=v_{b} / \sqrt{u_{b}^{2}+v_{b}^{2}}
\end{gathered}
$$

ここに， $u_{b}=$ 底面での $x$ 方向流速 $\left(=U-u^{\prime}\right), v_{b}=$ 底面での $y$ 方向流速 $\left(=V-v^{\prime}\right)$ である. また，全流砂量 $q_{B T}$ と粒径別流 砂量 $q_{B j}$ には式(8)の関係がある.

$$
q_{B T}=\sum_{j=1}^{N} q_{B j}
$$

ここに， $N=$ 粒径の分割数である. 粒径別流砂量 $q_{B i}$ の算 定には，遮蔽効果に修正エギアザロフ式を適用した式(9) の芦田・道上 ${ }^{21)}$ の流砂量式を用いた。 なお，無次元有効 掃流力は，抵抗則と整合するように無次元掃流力とした.

$$
\begin{aligned}
& q_{B j}=F_{j} \cdot 17 \cdot \sqrt{s g D_{j}^{3}} \tau_{*_{j}}^{3 / 2}\left(1-\tau_{*_{c j}} / \tau_{*_{j}}\right)\left(1-u_{*_{c j}} / u_{*}\right) \\
& \frac{\tau_{*_{c j}}}{\tau_{*_{s c}}}=\left\{\begin{array}{cc}
0.843\left(D_{j} / D_{s g}\right)^{-1} & D_{j} / D_{s g} \leq 0.4 \\
{\left[\log _{10} 19 / \log _{10}\left(19 D_{j} / D_{s g}\right)\right]^{2}} & D_{j} / D_{s g}>0.4
\end{array}\right.
\end{aligned}
$$

ここに， $D_{j}=$ 交換層での $j$ 番目の土砂の粒径， $D_{s g}=$ 交換層 での平均粒径, $\tau_{* j}=D_{j}$ に対応する無次元掃流力, $u *=$ 摩擦 速度, $\tau_{* s c}=D_{s g}$ に対応する無次元限界掃流力である.

交換層厚 $L_{a}$ は式(10)より算定した.

$$
L_{a}=n_{a} D_{90}
$$

ここに $n_{a}$ は係数(ここでは $\left.n_{a}=1.0\right)$ である. 交換層と貯留層 との境界での粒度比率 $f_{I j}$ は，掃流砂の粒度が河床上昇時 に堆積層へ取り残される砂碩に及ぼす影響を考慮した Hoey and Ferguson ${ }^{22)}$ の式を用いた。

$$
f_{I j}=\left\{\begin{array}{cc}
F_{b j}(z)_{z=z_{b}-L_{a}} & \partial z_{b} / \partial t<0 \\
a F_{j}+(1-a) p_{B j} & \partial z_{b} / \partial t \geq 0
\end{array}\right.
$$

ここに $F_{b}(z)=$ 貯留層, $p_{B j}\left(=q_{B j} / q_{B T}\right)=$ 流砂量の粒度比率, $a=$ 重み係数であり, $a=0 \sim 1(こ こ て ゙ は ~ a=0.5)$ の值となる.

\section{（2）数值解法}

式(1), 式(5), 式(6)の離散化は, 有限体積法に基づき 行ったななお，時間積分にはEulerの陽解法を用いた，連 続の式と運動量・モーメントの保存式の数值流束には, HLLC 法 ${ }^{17)}$ に河床勾配の取り扱いを組み込んだ数值流束 を用いた，同数值流束の詳細については，参考文献 ${ }^{15)}$ 参照されたい. 河床変動の数值流束と粒度比率の数值流 束には，新しい時間ステップの粒度比率 $F_{j} か ゙ ~ \sum F_{j}=1 や 0 \leqq$ $F_{j} \leqq 1$ が満たされないなどの問題を避ける目的で，それ ぞれ風上型の数值流束を用いた. 同数值流束の詳細につ いては，参考文献 ${ }^{18)}$ を参照されたい.

\section{3. 実験の概要}

実験は，分流点上下流の本川の川幅が等しい場合 (CaseA), 狭い場合(CaseB)の2通りを想定し，流れの把握 を目的とした固定床(CaseA-a, CaseB-a), 河床変動特性 の把握を目的とした一様砂床(CaseA-b, CaseB-b), 混合 砂磎床(CaseA-c, CaseB-c)で行った.

実験装置は，図-2に示すような長さ $9.0 \mathrm{~m} \times$ 幅 $1.8 \mathrm{~m}$ の可 変勾配水路中にアクリル製の本川(長さ $9.0 \mathrm{~m}$ ，高さ $0.25 \mathrm{~m}$, 勾配 $I=1 / 1,000)$ と, 角度 $\theta=30^{\circ}$ で分流させた支川(長さ $2.6 \mathrm{~m}$, 幅 $B_{3}=0.25 \mathrm{~m}$, 高さ $0.25 \mathrm{~m}$, 勾配 $\left.I=1 / 1,000\right)$ を設置し たものである。分流点下流の本川の幅を, CaseAでは $B_{2}=0.5 \mathrm{~m}$, CaseBでは $B_{2}=0.3 \mathrm{~m}$ と変化させた. 本・支川下 流端には四角堰が設置されており，本川については堰幅 によって水位を調節できるようになっている. 図中の本 川の諸量には分流点上流と下流でそれぞれ下付けの添字 1と2を，支川の諸量には下付けの添字3を付している.

表-1に各Caseの実験条件を示す. CaseA-a とCaseB-aで 流況を把握した後, CaseA-aおよびCaseB-aと同一な流入 条件や下流端の堰幅等の条件下で一様砂床，混合砂礫床 実験(CaseA-b・c, CaseB-b・c)を行った. CaseA・B-bで 

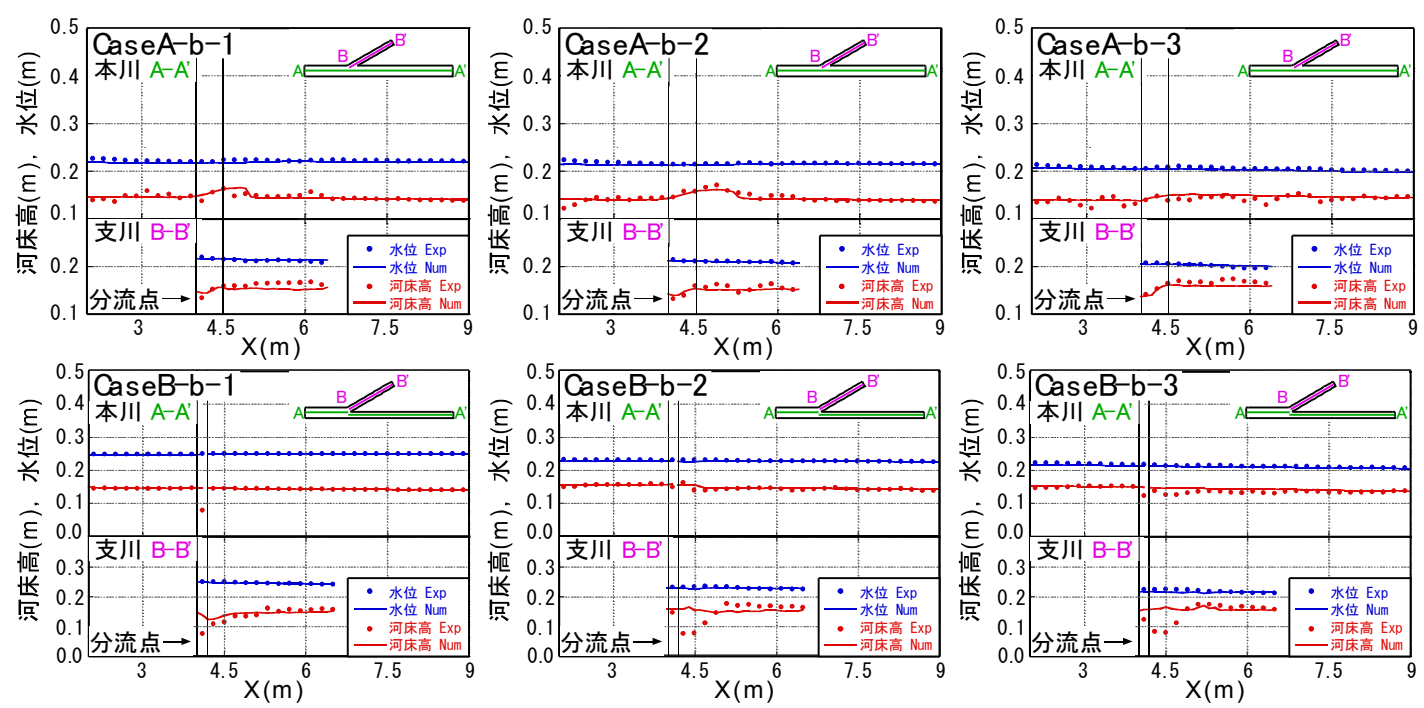

図-4 水路中心軸での水面 · 河床形状の比較
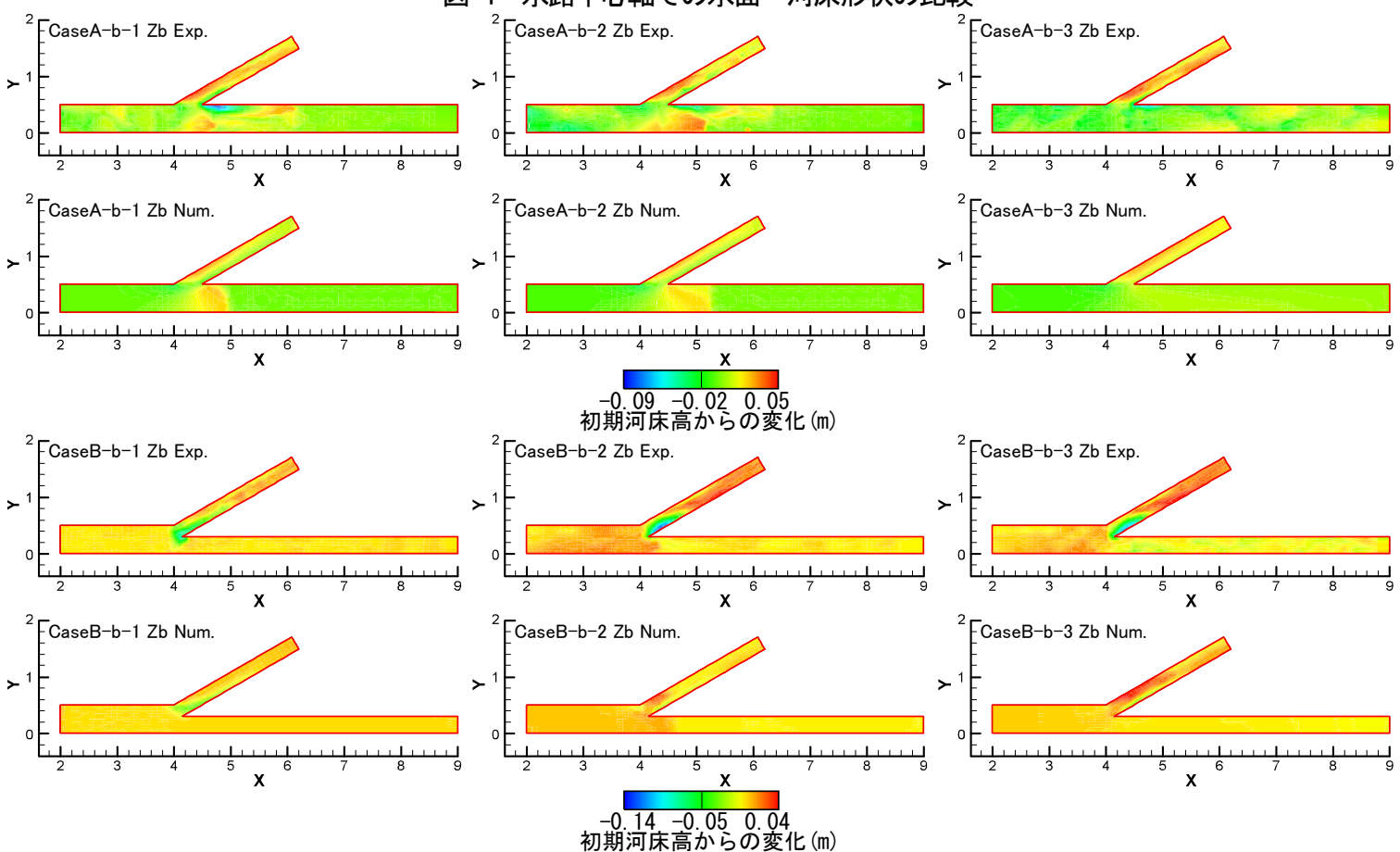

図-5＼cjkstart初期河床を基準面とした河床高コンターの比較
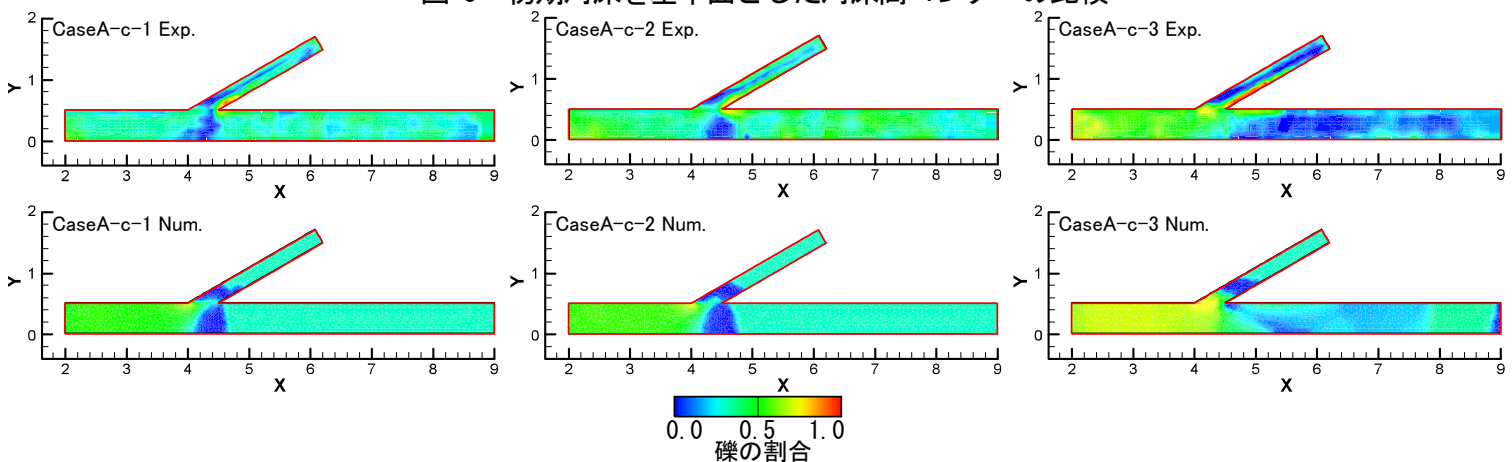

\section{図-6 河床表層材料中の礫の割合}

は粒径 $D=0.89 \mathrm{~mm}$, 水中比重 $s=1.65$ の一様砂を, CaseA ・ B-cでは粒径 $3.75 \mathrm{~mm}$ の碩と粒径 $0.89 \mathrm{~mm}$ の砂を $3: 7$ の割合 で混合し, 平均粒径 $1.75 \mathrm{~mm}$, 水中比重1.67の混合砂砅を 高さ $0.14 \mathrm{~m}$ で敷き詰めた. 測定項目は, 水位 $H(\mathrm{~m})$, 河床 高 $Z_{\mathrm{b}}(\mathrm{m})$, 分派流量 $Q_{3}\left(\mathrm{~m}^{3} / \mathrm{s}\right)$ および分派流砂量 $Q_{\mathrm{s} 2}$, $Q_{\mathrm{s} 3}\left(\mathrm{~m}^{3} / \mathrm{s}\right)$ および河床表層と分派流砂量の粒度分布である.
移動床実験では上流から一定流量 $Q_{1}=0.015\left(\mathrm{~m}^{3} / \mathrm{s}\right)$ を供給 し，下流端から流出した土砂と同量の給砂を行い，本・ 支川の流量および流砂量が一定であり，目視で河床高に 大きな変化がなくなったことを確認した後，測定を開始 した，水位はポイントゲージで，河床高はレーザー変位 計で測定した. 分派流量はバケツで水を回収し，分派流 


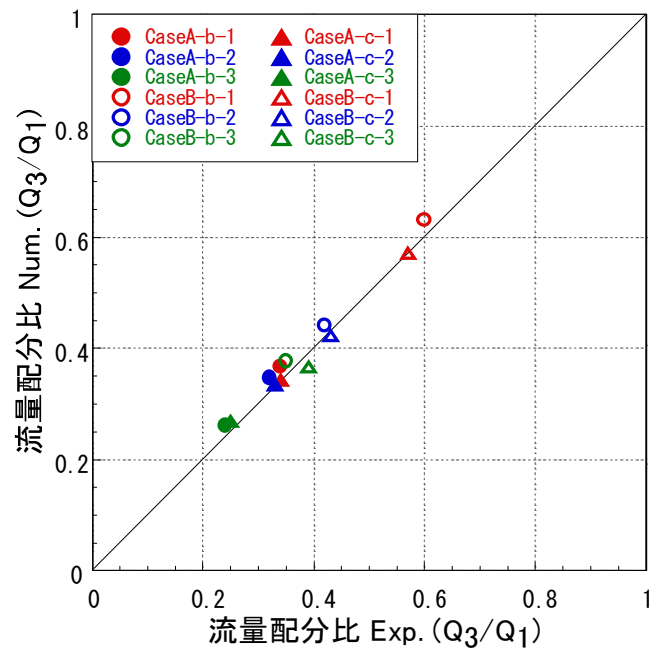

図-7 分派流量の比較

表-2 分派流砂量比の比較

\begin{tabular}{|c|c|c|}
\hline \multirow{2}{*}{} & \multicolumn{2}{|c|}{ 流砂量比 $\left(\mathrm{Q}_{\mathrm{s} 3} /\left(\mathrm{Q}_{\mathrm{s} 2}+\mathrm{Q}_{\mathrm{s} 3}\right)\right)$} \\
\cline { 2 - 3 } & Exp. & Num. \\
\hline CaseA-b-1 & 0.98 & 1.00 \\
\hline CaseA-b-2 & 0.97 & 1.00 \\
\hline CaseA-b-3 & 0.68 & 0.30 \\
\hline CaseA-c-1 & 0.65 & - \\
\hline CaseA-c-2 & 0.79 & - \\
\hline CaseA-c-3 & 0.04 & 0.00 \\
\hline CaseB-b-1 & 1.00 & 1.00 \\
\hline CaseB-b-2 & 0.93 & 1.00 \\
\hline CaseB-b-3 & 0.16 & 0.26 \\
\hline CaseB-c-1 & 0.93 & 1.00 \\
\hline CaseB-c-2 & 0.56 & 0.00 \\
\hline CaseB-c-3 & 0.01 & 0.00 \\
\hline
\end{tabular}

砂量はふるいで砂を回収し，それぞれ水の体積および砂 の重量と時間を計測することで算定した。河床表層での 砂砂の割合は，図-3のように，デジタルカメラを用いて 河床表層の写真を撮影し，2值化した画像を，画像解析 ソフトを用いて面積比を算出することで求めた。 なお,

同手法の妥当性は，あらかじめ設定した表層での砂礫の 割合を $\pm 5 \%$ の誤差で再現できたことから確認されてい る. 水位と河床表層の砂礫の割合の測定範囲および測定 点は図-2に示寸通りである.

\section{4. モデルの検証}

以下では, 一様砂床と混合砂碟床での実験結果 $($ CaseA-b・c， CaseB-b・c)に基づき本モデルの河床変動 の再現性について検討する. なお，本モデルの分流点周 辺での流れの再現性については, 参考文献(1) と同程度の 精度で水位・底面流線等の実験結果の再現できることが 確認されている.

解析では各Caseの解析対象領域を1537 2102個の三角 セルで解析領域を分割した。流れの境界条件には上下流 端にそれぞれ流量と水位を, 河床変動の境界条件には上 流端には流下方向の流砂量(横断方向は0)を，下流端には 計算過程で射流が生じた場合に備え河床高を与えた。 な
お，河床材料の空隙率 $\lambda_{b}=0.4$ 与えた.

図-4はCaseA-b-1 3，CaseB-b-1 3の本川・支川の水路 中心軸での水面と河床形状について，図-5は初期河床を 基準面とした河床高コンターについて, 解析結果と実験 值との比較を行ったものである. 河床コンター図では初 期河床から土砂が堆積した場合は正の值，洗掘した場合 は負の值となる. 本モデルは, 図-4の本・支川の水路中 心軸については(1) CaseB-2，3の局所洗掘を除き，水面 および河床形状を再現できること，図-5の(2) CaseA-bの 支川左岸側で堆積が生じること，(3) CaseA-b-1と2の分 流点下流の本川右岸側で堆積が生じること, 一方CaseAb-3では分流点下流の本川右岸側で堆積が生じないこと, (4) 本川右岸堆積の程度はCaseA-b-2で最大となること, (5) CaseB-bでは支川右岸側で洗掘が生じること，(6) CaseB-b-2や3では本川上流で堆積が生じること，などを 再現できることが確認できる. 一方，(1) CaseA-b， B-b の支川右岸側の局所洗掘, (2) CaseA-b-1，2の本川左岸 側での局所洗掘，(3) CaseB-b-1では分流点周辺での局所 洗掘，などを再現できないことが確認できる.

次に，混合砂㗂河床の移動床実験に基づき本モデルを 検証した. なお，水面・河床形状や河床コンターの再現 性については，上記の一様砂床と同様な予測精度であっ たのでここでは，紙面の都合上，CaseA-c-1 3の河床 表層材料中の㗂の割合についてのみ述べる，図-6は CaseA-c-1 3の本川・支川の河床表層材料中の碩の割合 について解析結果と実験值との比較を行ったものである. これより，本モデルは，(1) 分流点上流では主に砂が流 送されるため, 礫の割合が高くなる様子, (2) 分流点周 辺では砂が磁上で堆積するため, そこでの碟の割合が小 さくなる様子，などを再現できることが確認できる．一 方，(3) 分流点周辺の局所洗掘を再現できないために, そこでの碩の割合などを再現できないことが確認できる。

最後に, 分流点での分派流量と分派流砂量の実験結果 に基づき，本モデルを検証した．図一7は分派流量の比較 を, 表-2は, 分派流砂量比の比較を行ったものである. なお，表-2中のCaseA-c-1 と2で值を示していないのは， いずれも分派流砂量 $Q_{\mathrm{s} 2}, Q_{\mathrm{s} 3}$ が0であったためである. こ れより, (1) 分派流量は1割程度の誤差の範囲で再現でき るが，(2)分派流砂量は，再現できないことが確認できる. これは, 分派流量は, 積分值であり下流端条件で決まる ため，定常であれば，分派地点での流速分布等が少々異 なっても再現できるのに対し, 分派流砂量は分派地点で の流速分布等に大きく影響するため, 局所洗掘などを再 現できない本モデルでは誤差が生じたと考えられる.

以上，本モデルは，分流点周辺の流れをある程度再現 できることが確認された. 一方で, 局所洗掘等, 分流点 の分派流砂量等を決定する要因となる現象を再現できな いことがわかった。これは，本モデルが，静水圧分布を 仮定した準3次元モデルであり，鉛直方向の流れを考慮 できないためである，これらを踏まえると，本モデルを 
中長期の河床変動を予測可能にするためには，まず，非 静水圧分布を考慮できるモデルとする必要がある. その 場合，当然計算負荷が大きくなるため，本モデルのよう な静水圧モデルと非静水圧モデルのハイブリッドモデル を構築し，計算効率の向上を図る必要がある.

\section{5. おわりに}

本研究では，著者らの開発した準3次元河床変動モデ ル ${ }^{15)}$ に，モーメント方程式に鉛直方向の流速分布に応じ たせん断応力と底面せん断力に底面流速の影響を組み込 むとともに，モーメント方程式の離散化に，HLL法 ${ }^{16)}$ りも数值拡散が小さいHLLC法 ${ }^{17)}$ を適用するなどの改良 を加え, 混合砂碟河床変動モデル ${ }^{18)}$ を導人することで, 新たな準3次元混合砂碟河床変動モデルを構築した．同 モデルを分流点周辺の一様砂および混合砂碩河床での移 動床実験結果に適用し検証した結果，同モデルが分流点 周辺の河床変動や河床の質を概ね再現可能であるが，局 所洗掘等を再現できないために，分派流砂量等の再現に 問題が残った. 今後は，本モデルを，非静水圧を取り扱 うことが可能なモデルとするとともに，本モデルと非静 水圧モデルのハイブリッドモデルを構築することで計算 効率の向上を図り, 維持管理計画を策定するツールとし たい.

謝辞：本研究は，科学研究費補助金若手研究 $\mathrm{B}($ 課題番 号 : 25820225, 研究代表者 : 重枝未玲)の助成を受け実 施したものである. 本研究を遂行するに当り，本学学部 4年生の平松裕樹君，田尻富岳君には，データ整理等で 協力を得た. ここに記して感謝の意を表します.

\section{参考文献}

1)国土交通省：河川砂防技術基準維持管理編, http://www.mlit.go.jp/river/shishin_guideline/gijutsu/gijutsukijun n/ijikanri/kasen/pdf/gijutsukijun.pdf, 2011.

2) 清水康行 : 河道平面形状の形成における河床・河岸の変動 特性の相互関係について，水工学論文集，第47巻，pp.643648, 2003.

3) 関根正人 : 斜面崩落モデルを用いた網状流路の形成過程シ ミュレーション，水工学論文集，第47巻，pp.637-642， 2003.

4) 坊野聡子, 清水康行, 黒木幹男, 藤田睦博, 吉田義一: ダ ムを含む河川の流砂と河床変動に関する研究，土木学会論 文集，No.565/II-52，pp.61-72，2000.

5) 池田駿介, Gary Parker, 千代田将明，木村善孝: 直線磕床 河川の動的安定横断形状とそのスケール，土木学会論文集， 第375巻/II-6, pp.117-126, 1986.

6) 浅野文典, 福岡捷二 : 沖積地河川における安定な川幅・水 深一治水と環境の調和を目指した河道断面形の決め方，水
工学論文集, 第54巻, pp.1021-1026, 2010.

7) 室田 明: 開水路分水工の研究，土木学会論文集，第70号 別冊1-1, pp.1-33, 1960.

8）芦田和男，川合茂：分岐部周辺における流れの水理特性 について, 京都大学防災研究所年報, 第22号 B-2, pp.491-506, 1979.

9）川合 茂，芦田和男：固定床開水路分流における流量・流 量配分比に関する実験的研究，土木学会論文集，第405号 /II-1, pp.139-146, 1989.

10）横山洋，渡邊康玄，鈴木優一：分岐・合流流れを有する 河川における河床変動計算に関する研究，北海道開発土 木研究所月報, No.615号, pp.2-9, 2004.

11) 星野 剛, 安田浩保, 永多朋紀 : 四分木構造格子を導入し た自然河川における分岐点と合流点の数值解法, 土木学 会論文集B1(水工学), Vol.68, No.4, I_853-I_858, 2012.

12) 重枝未玲, 秋山 壽一郎, 才木康裕, 西藤安隆: 分流・合 流部を有する河道での流れと河床変動の数值シミュレー ション，水工学論文集，第52巻，pp.619-624， 2008.

13）輿石 大, 内田龍彦, 福岡捷二 : 水表面流速方程式を付加 した底面流速解析法の開発と河川合流部一の適用，土木 学会論文集B1(水工学)，Vol.68，No.4，I_835-I_840，2012.

14) 坂本 洋, 重枝未玲, 秋山壽一郎 : 準3次元洪水流モデル を用いた同規模河川合流点流れの数值解析，土木学会論 文集B1(水工学)，Vol.68，No.4，I_841-I_846， 2012.

15) 坂本 洋, 重枝未玲, 秋山壽一郎, 新谷恭平: 準3次元河 床変動モデルの構築と河川合流点の河床変動への適用, 土木学会論文集B1(水工学) Vol.69, No.4, I_991-I_996, 2013.

16) Hatern, A., Lax, P.D. and van Leer, B.: On upstream differencing and Godunov-type schemes for hyperbolic conservation laws, SIAM Review, Vol.25, No.1, pp.35-61, 1983.

17) Toro, E. F., Spruce, M. and Speares, W.: Restoration of the contact surface in the HLL Riemann solver, Shock Waves, Vol.4, pp.25-34, 2004.

18）重枝未玲, 秋山壽一郎, 坂本 洋 : 混合砂礫河床変動乇 デルの構築と粗粒化・細粒化を伴う河床変動への適用, 土木学会論文集B1(水工学), Vol.68, No.4, I_1189-I_1194, 2012.

19) 岸力, 黒木幹男 : 移動床における河床形状と流体抵抗(I), 北海道大学工学部研究報告, No. 67, pp. 1-23, 1973.

20) 平野宗夫 : Armoringを伴う河床低下について, 土木学会論 文報告集，第195号，pp.55-65，1971.

21）芦田和男，道上正規 : 移動床流れの抵抗と掃流砂量に関す る基礎的研究，土木学会論文報告集，第206号，pp.59-69， 1972.

22) Hoey, T. B. and Ferguson, R. I.: Numerical simulation of downstream fining by selective transport in gravel bed rivers: Model development and illustration, Water Resources and Research, Vol.30, pp.2251-2260, 1994.

(2013. 9. 30受付) 